\title{
ABSTRAK \\ MENGAJARKAN POTENSI PERTANIAN LOKAL KAB. GROBOGAN MELALUI MODEL PEMBELAJARAN TERPADU DI SEKOLAH MENENGAH PERTAMA
}

\author{
Ahmad Muhlisin, Dosen IKIP Budi Utomo Malang, Jawa Timur, \\ 085641142622, E-mail: nisil.m.ahmad@gmail.com
}

Upaya mencapai kedaulatan pangan, pembangunan pertanian saat ini dihadapkan ke dalam berbagai tantangan yang harus dihadapi bersama. Keberhasilan pembangunan pada sektor pertanian ditentukan oleh ketersediaan sumberdaya manusia yang mumpuni. Untuk dapat menyediakan sumberdaya yang memadai, maka perlu adanya pendidikan yang mengintegrasikan potensi tersebut dalam pembelajaran. Dalam mewujudkannya diperlukan cara menginterintegrasikan potensi pertanian lokal melalui pembelajaran IPA terpadu agar potensi tersebut tetap terjaga dan dapat dikembangkan lebih lanjut. Integrasi potensi pertanian lokal dalam pembelajaran terpadu dapat dilaksanakan dengan pengambilan tema pertanian lokal yang ada didaerah tersebut. Seperti halnya contoh pemaduan dalam tema "padiku subur hidupku makmur" yang dapat diintegrasikan halhal yang berkaitan dengan pertanian padi sebagai produk potensi lokal setempat.

Kata kunci: pertanian local, pembangunan pertanian

\begin{abstract}
In an effort to achieve food sovereignty, agricultural development is currently exposed to the various challenges that must be faced together. The successful development of the agricultural sector is determined by the availability of qualified human resources. To be able to provide adequate resources, the need for education that integrates the potential of learning. In a way necessary to make it happen to interated the local agriculture through integrated science learning that this potential can be maintained and developed further. Integration of the local agriculture in integrated learning can be implemented by making existing local agricultural theme in the area. Just as an example of the integration of the theme "rice fertile prosperous life" that can be integrated matters related to rice farming as a product of local potential.
\end{abstract}

Keyword: Local agriculture, agricultural development 
Sektor pertanian Kabupaten Grobogan merupakan sektor primer yang strategis, karena memberi kontribusi 43,6\% dari PDRB Kabupaten Grobogan setiap tahun. Pendapatan perkapita masyarakat Kabupaten Grobogan tergantung pada keberhasilan sektor pertanian. Terdapat 7 (tujuh) komoditas utama yang menjadi pendapatan masyarakat di Kabupaten Grobogan, yaitu: padi, jagung, kedelai, kacang hijau, semangka, melon serta ternak sapi (DISPERTAN Grobogan, 2013). Hal tersebut merupakan keunggulan lokal daerah kabupaten Grobogan yang harus dipertahankan keberadaannya dan ditingkatkan produktivitasnya agar kebutuhan manusia tetap terjaga.

Keunggulan lokal adalah hasil bumi, kreasi seni, tradisi, budaya, pelayanan, jasa, sumber daya alam, sumber daya manusia atau lainnya yang menjadi keunggulan suatu daerah Depdiknas (2008). Kabupaten Grobogan, dikenal sebagai lumbung padi nasional, bahkan sebagai tempat lahirnya varietas tanaman jenis baru. Sebagian besar penduduknya $( \pm 53 \%)$ menggantungkan hidupnya pada bidang pertanian ini, dan kontribusi terbesar terhadap PDRB
Kabupaten Grobogan juga berasal dari lapangan usaha tersebut (PEMKAB Grobogan, 2013).

Berdasarkan angka sementara tahun 2012, produksi beberapa komoditas strategis yakni: (1) produksi padi mencapai 628.569 ton pada luas area 109.867 ha, (2) produksi jagung sebanyak 575.614 ton pada luas panen 100.332 ha, (3) produksi kedelai sebanyak 65.755 ton pada luas panen 27.170 ha, (4) produksi kacang hijau mencapai 25.829 ton pada luas area 22.385 ha, (5) produksi semangka mencapai 8.486 ton pada luas area 457 ha, dan (6) produksi melon mencapai 8.280 ton pada luas area 429 ha (DISPERTAN Grobogan, 2013). Keberhasilan pembangunan pertanian ditentukan oleh ketersediaan sumberdaya manusia yang mumpuni. Untuk dapat menyediakan sumberdaya yang memadai, maka perlu adanya pendidikan yang mengintegrasikan potensi tersebut dalam pembelajaran.

Selama ini, potensi pertanian lokal belum pernah diintegrasikan dalam pembelajaran. Implementasi integrasi potensi pertanian lokal dapat diintegrasikan dalam pembelajaran IPA terpadu pada sekolah menengah. Banyak 
tema atau topik yang terkait dengan potensi pertanian lokal yang dapat digunakan menjadi titik fokus dalam pembelajaran. Tema atau topik tersebut dapat dikaji melalui satu disiplin ilmu atau lintas disiplin ilmu yang terkait, sehingga pemahaman siswa dapat menjadi utuh.

Pengintegrasian potensi pertanian lokal dalam pembelajaran IPA terpadu dapat membantu siswa dalam memahami pertanian lokal yang ada terkait tema atau topik yang digunakan. Memahami konsep-konsep yang ada dalam pertanian lokal membuat siswa memperoleh pengetahuan bermakna dalam pembelajaran yang secara nyata dijumpai dalam kehidupan siswa. Gagasan mengenai pembelajaran yang mengintegrasikan dengan potensi pertanian lokal dapat dilakukan melalui pembelajaran IPA terpadu agar potensi tersebut tetap terjaga dan dapat dikembangkan lebih lanjut.

\section{PEMBAHASAN}

\section{Potensi Pertanian Lokal Kab. Grobogan}

Penduduk kabupaten Grobogan, sebagian besar tinggal di daerah pedesaan, karena itu sesuai potensi daerah yang agraris, maka mata pencaharian penduduk kabupaten Grobogan sebagian besar bekerja dibidang pertanian, baik sebagai buruh tani atau petani penggarap. Sedangkan sebagian lainnya bekerja sebagai pegawai, pedagang, dan lain-lain. Adapun komposisi jenis pekerjaan penduduk kabupaten Grobogan pada tahun 2012 yang bekerja di bidang pertanian mencapai $52 \%$, diikuti bidang perdagangan $17 \%$, sedangkan bidang perikanan paling sedikit yaitu $0,10 \%$ (PEMKAB Grobogan, 2013). Komposisi penduduk kabupaten Grobogan umur 15 tahun keatas menurut mata pencaharian tahun 2008-2012 lapangan pekerjaan tertinggi yakni: (1) pertanian tanaman pangan mencapai 390.809, perdagangan mencapai 129.824 , (3) jasa mencapai 63.938, (4) perkebuman mencapai 15.273, dan (5) peternakan mencapai 8.664 (BPS Grobogan, 2012). Berdasarkan hal tersebut sektor pertanian merupakan mayoritas mata pencaharian penduduk masyarakat kabupaten Grobogan, oleh sebab itu diperlukan pendidikan untuk meningkatkan sektor pertanian kepada masyarakat agar pertanian dapat ditingkatkan. Sektor pertanian kabupaten Grobogan meliputi 
produksi padi, produksi jagung, produksi kedelai, produksi kacang hijau, produksi semangka, dan produksi melon.

Kabupaten Grobogan merupakan salah satu daerah penyangga pangan terbesar Propinsi Jawa Tengah. Pada tahun 2011 produksi padi Grobogan mencapai 602.635 ton, terdiri padi sawah 574.615 ton dan padi gogo 28.020 ton.Produksi jagung rata-rata selama 10 tahun terakhir mencapai 448.389 ton pertahun dengan luas panen 106.130 hektare. Sedangkan tahun 2011 produksi jagung mencapai 564.453 ton pipil kering dan memberikan kontribusi 16,84 persen terhadap produksi jagung Propinsi Jawa Tengah. Khusus untuk tanaman kedelai, jenis kedelai yang ditanam petani adalah kedelai varietas Grobogan. Varietas ini berasal dari seleksi populasi kedelai lokal yang kemudian telah dilepas menjadi varietas unggul nasional pada tahun 2008. Kedelai jenis ini memiliki keunggulan, yaitu berumur sangat pendek (76 hari); ukuran polong besar (18 gram per 100 biji), produksi tinggi (rata-rata hasil 2 ton per ha), dan kandungan protein tinggi $(43,9 \%)$ lebih tinggi dibanding kedelai impor. Itulah sebabnya permintaan benih kedelai varietas Grobogan dari waktu ke waktu semakin meningkat, baik di wilayah Jawa maupun luar Jawa.

\section{Pembelajaran Terpadu}

Model pembelajaran terpadu merupakan salah satu model pembelajaran yang trend dilakukan dewasa ini. Dalam implementasi standar kompetensi dan kompetensi dasar, telah dilakukan berbagai studi yang mengarah pada peningkatan efisiensi dan efektivitas layanan dan pengembangan sebagai konsekuensi dari suatu inovasi pendidikan. Salah satu bentuk efisiensi dan efektivitas implementasi kurikulum dikembangkan berbagai model implementasi kurikulum. Model pembelajaran terpadu merupakan salah satu model implementasi kurikulum yang dianjurkan untuk diaplikasikan pada semua jenjang pendidikan, mulai dari tingkat Sekolah Dasar/Madrasah Ibtidaiyah (SD/MI) sampai dengan Sekolah Menengah Atas/Madrasah Aliyah (SMA/MA). Model pembelajaran ini pada hakikatnya merupakan suatu pendekatan pembelajaran yang memungkinkan peserta didik baik secara individual maupun kelompok aktif mencari, menggali, dan menemukan konsep serta 
prinsip secara holistik dan otentik (Balitbang Depdiknas, 2006).

Melalui pembelajaran IPA terpadu, peserta didik dapat memperoleh pengalaman langsung, sehingga dapat menambah kekuatan untuk mencari, menyiapkan, dan menerapkan konsep yang telah dipelajarinya. Dengan demikian, peserta didik terlatih untuk dapat menemukan sendiri berbagai konsep yang dipelajari secara menyeluruh (holistik), bermakna, otentik dan aktif. Hal tersebut sesuai dengan pendapat Hidayat (2009) menyebutkan bahwa pembelajaran IPA terpadu model connected efektif dalam meningkatkan hasil belajar, meningkatkan aktivitas siswa dalam mengikuti pembelajaran serta mampu menghubungkan antar konsep dalam mata pelajaran IPA SMP/MTs sehingga akan memudahkan bagi mereka untuk memahami konsep-konsep IPA dan memecahkan masalah yang dihadapinya.

Model pembelajaran IPA Terpadu juga memiliki kelemahan sebagai berikut ini.

a. Aspek Guru: Guru harus berwawasan luas, memiliki kreativitas tinggi, keterampilan metodologis yang handal, rasa percaya diri yang tinggi, dan berani mengemas dan mengembangkan materi. Secara akademik, guru dituntut untuk terus menggali informasi ilmu pengetahuan yang berkaitan dengan materi yang akan diajarkan dan banyak membaca buku agar penguasaan bahan ajar tidak terfokus pada bidang kajian tertentu saja. Tanpa kondisi ini, maka pembelajaran terpadu dalam IPA akan sulit terwujud.

b. Aspek peserta didik: Pembelajaran terpadu menuntut kemampuan belajar peserta didik yang relatif "baik", baik dalam kemampuan akademik maupun kreativitasnya. Hal ini terjadi karena model pembelajaran terpadu menekankan pada kemampuan analitik (mengurai), kemampuan asosiatif (menghubung-hubungkan), kemampuan eksploratif dan elaboratif (menemukan dan menggali). Bila kondisi ini tidak dimiliki, maka penerapan model pembelajaran terpadu ini sangat sulit dilaksanakan.

c. Aspek sarana dan sumber pembelajaran: Pembelajaran terpadu memerlukan bahan bacaan atau sumber informasi yang cukup banyak dan bervariasi, mungkin juga fasilitas internet. Semua ini akan menunjang, 
memperkaya, dan mempermudah pengembangan wawasan. Bila sarana ini tidak dipenuhi, maka penerapan pembelajaran terpadu juga akan terhambat.

d. Aspek kurikulum: Kurikulum harus luwes, berorientasi pada pencapaian ketuntasan pemahaman peserta didik (bukan pada pencapaian target penyampaian materi). Guru perlu diberi kewenangan dalam mengembangkan materi, metode, penilaian keberhasilan pembelajaran

e. Aspek penilaian: Pembelajaran terpadu membutuhkan cara penilaian yang menyeluruh (komprehensif), yaitu menetapkan keberhasilan belajar peserta didik dari beberapa bidang kajian terkait yang dipadukan. Dalam kaitan ini, guru selain dituntut untuk menyediakan teknik dan prosedur pelaksanaan penilaian dan pengukuran yang komprehensif, juga dituntut untuk berkoordinasi dengan guru lain, bila materi pelajaran berasal dari guru yang berbeda.

f. Suasana pembelajaran: Pembelajaran terpadu cenderung mengutamakan salah satu bidang kajian dan ‘tenggelam'nya bidang kajian lain.
Dengan kata lain, pada saat mengajarkan sebuah TEMA, maka guru berkecenderungan menekankan atau mengutamakan substansi gabungan tersebut sesuai dengan pemahaman, selera, dan latar belakang pendidikan guru itu sendiri.

Perubahan pendekatan pembelajaran IPA menuntut guru untuk memahami dan menyesuaikannya. Selama ini guru IPA telah terbiasa dengan pembagian tugas sebagai guru fisika dan guru biologi, sekarang mereka harus dapat mengajarkan fisika, biologi dan kimia secara keseluruhan, baik secara individu maupun dengan bekerja sama dalam team teaching. Perubahan pendekatan pembelajaran ini bukanlah hal yang mudah bagi mereka yang telah bertahuntahun mengajarkan mata pelajaran secara terpisah (Hidayat, 2009).

Pembelajaran terpadu berdasarkan sifat keterpaduannya dapat dibedakan menjadi tiga, yakni model dalam satu disiplin ilmu (model yang masuk ke dalam kelompok ini antara lain adalah fragmented model, connected model, nested model), model antar bidang (model keperpaduan yang masuk ke dalam kelompok ini antara lain sequenced model, 
shared model, webbed model, threaded lain immersed model dan networked model, integrated model), dan model model) (Balitbang Depdiknas, 2006).

dalam lintas siswa (model keperpaduan Indrawati (2009) mendeskripsikan yang masuk ke dalam kelompok ini antara sepuluh model pembelajaran terpadu seperti ditunjukkan pada Tabel 1.

Tabel 2.1 Ragam Model Pembelajaran terpadu

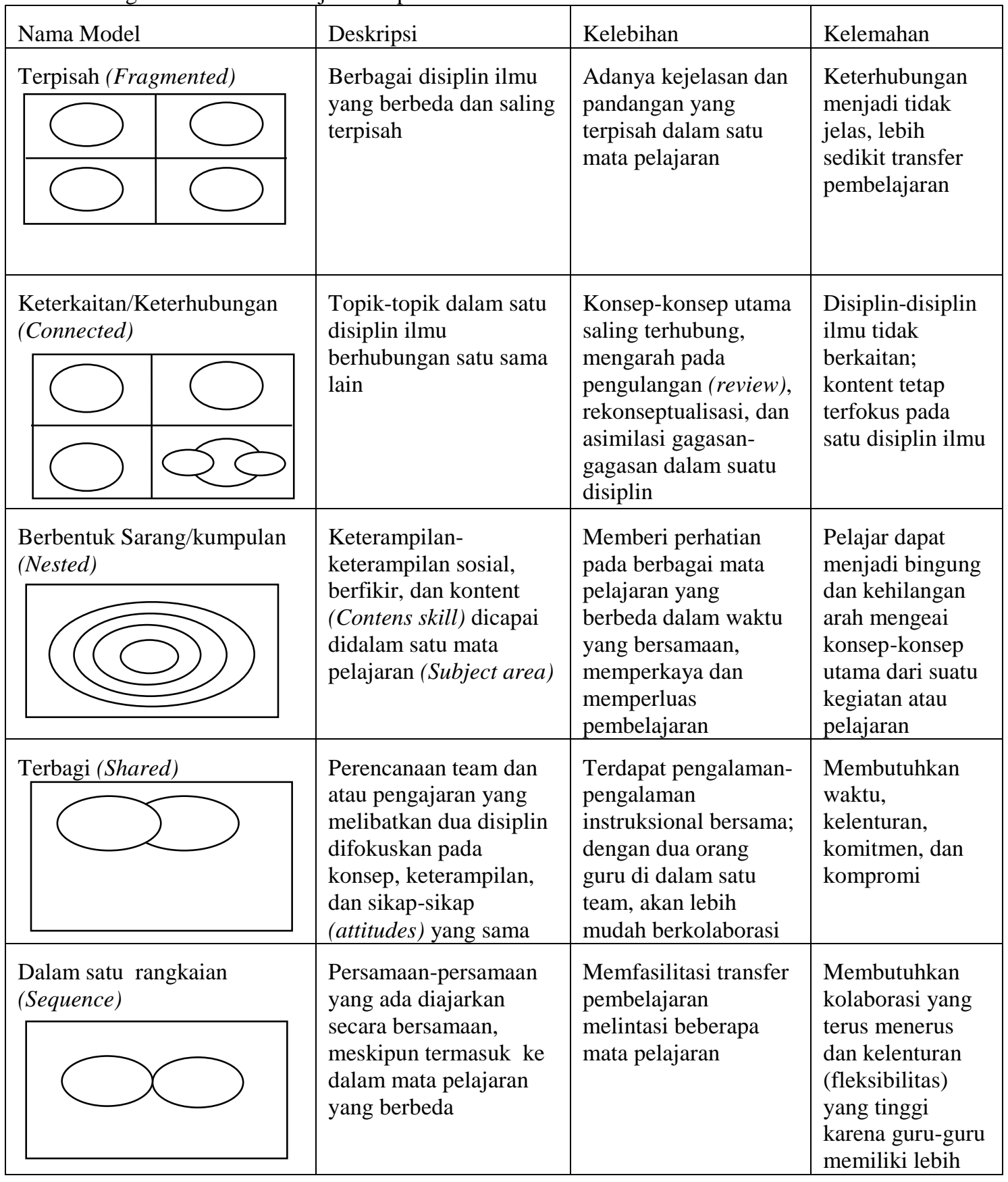




\begin{tabular}{|c|c|c|c|}
\hline & & & $\begin{array}{l}\text { sedikit otonomi } \\
\text { untuk } \\
\text { mengurutkan } \\
\text { (merancang) } \\
\text { kurikula } \\
\end{array}$ \\
\hline $\begin{array}{l}\text { Berbentuk jaring laba-laba } \\
\text { (Webbed) }\end{array}$ & $\begin{array}{l}\text { Pengajaran tematis, } \\
\text { menggunakan suatu } \\
\text { tema sebagai dasar } \\
\text { pembelajaran dalam } \\
\text { berbagai disiplin mata } \\
\text { pelajaran }\end{array}$ & $\begin{array}{l}\text { Dapat memotivasi } \\
\text { murid-murid: } \\
\text { membantu murid- } \\
\text { murid untuk melihat } \\
\text { keterhubungan antar } \\
\text { gagasan }\end{array}$ & $\begin{array}{l}\text { Tema yang } \\
\text { digunakan harus } \\
\text { dipilih baik-baik } \\
\text { secara selektif } \\
\text { agar menjadi } \\
\text { berarti, juga } \\
\text { relevan dengan } \\
\text { content }\end{array}$ \\
\hline Dalam satu alur (Threaded) & $\begin{array}{l}\text { Keterampilan- } \\
\text { keterampilan sosial, } \\
\text { berfikir, berbagai jenis } \\
\text { kecerdasan, dan } \\
\text { keterampilan belajar } \\
\text { direntangkan memalui } \\
\text { berbagai disiplin }\end{array}$ & $\begin{array}{l}\text { Murid-murid } \\
\text { mempelajari cara } \\
\text { mereka belajar, } \\
\text { memfasilitas transfer } \\
\text { pembelajaran } \\
\text { selanjutnya }\end{array}$ & $\begin{array}{l}\text { Disiplin-disiplin } \\
\text { ilmu yang } \\
\text { bersangkutan } \\
\text { tetap terpisah } \\
\text { satu sama lain }\end{array}$ \\
\hline Terpadu (Integrat & $\begin{array}{l}\text { Dalam berbagai } \\
\text { prioritas yang saling } \\
\text { tumpang tindih dalam } \\
\text { berbagai disiplin ilmu, } \\
\text { dicari keterampilan, } \\
\text { konsep, dan sikap-sikap } \\
\text { yang sama }\end{array}$ & $\begin{array}{l}\text { Mendorong murid- } \\
\text { murid untuk melihat } \\
\text { keterkaitan dan } \\
\text { kesalingterhubungan } \\
\text { di antara disiplin- } \\
\text { disiplin ilmu; murid- } \\
\text { murid termotivasi } \\
\text { dengan melihat } \\
\text { berbagai keterkaitan } \\
\text { tersebut }\end{array}$ & $\begin{array}{l}\text { Membutuhkan } \\
\text { team } \\
\text { antardepartemen } \\
\text { yang memiliki } \\
\text { perencanan dan } \\
\text { waktu } \\
\text { pengajaran yang } \\
\text { sama }\end{array}$ \\
\hline $\begin{array}{l}\text { Membentuk jejaring } \\
\text { (Networked) }\end{array}$ & $\begin{array}{l}\text { Murid-murid } \\
\text { melakukan proses } \\
\text { pemaduan topik yang } \\
\text { dipelajari melalui } \\
\text { pemilihan jejaring } \\
\text { pakar dan sumber daya }\end{array}$ & $\begin{array}{l}\text { Bersifat proaktif; } \\
\text { murid-murid } \\
\text { terstimulasi oleh } \\
\text { informasi, } \\
\text { keterampilan, atau } \\
\text { konsep-konsep baru }\end{array}$ & $\begin{array}{l}\text { Dapat memecah } \\
\text { perhatian murid- } \\
\text { murid, upaya- } \\
\text { upaya menjadi } \\
\text { tidak efektif }\end{array}$ \\
\hline
\end{tabular}




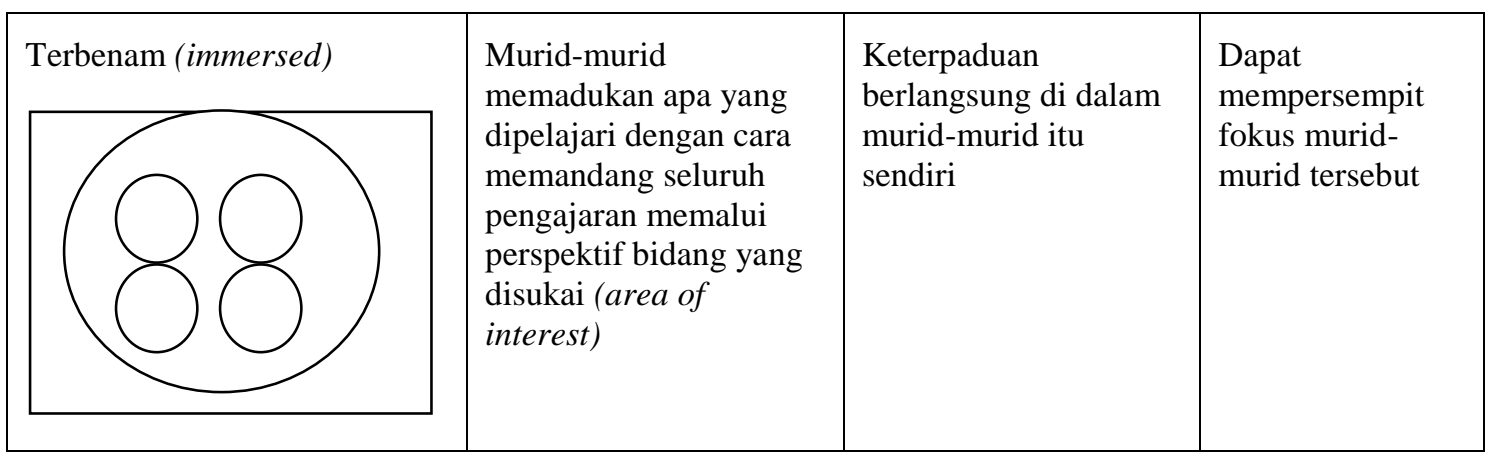
1.

Alur penyusunan perencanaan pembelajaran terpadu ditunjukkan oleh Gambar
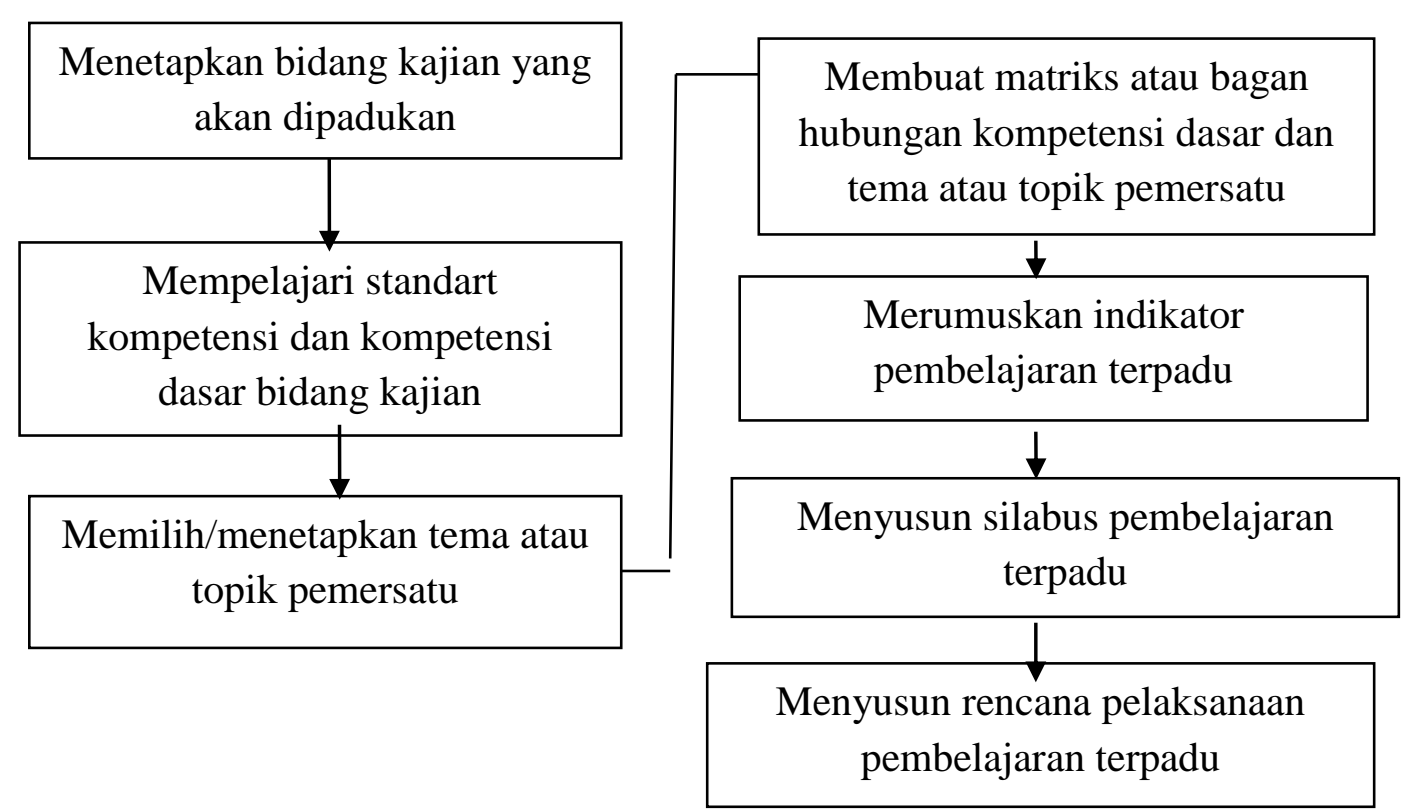

Gambar 1 Alur Penyusunan Perencanaan Pembelajaran Terpadu (Balitbang Depdiknas, 2006)

Pembelajaran terpadu, guru harus dengan pembelajaran biasa berlaku pula melakukan penilaian baik dalam proses dalam penilaian dengan pembelajaran pembelajaran maupun sebagai hasil proses terpadu. Hanya saja dalam penilaian hasil pembelajaran. Pada dasarnya penilaian belajar dengan pembelajaran terpadu hasil belajar peserta didik dalam alternatif penilaian banyak digunakan pembelajaran terpadu tidak berbeda dari tidak hanya bergantung pada penilaian tes penilaian untuk pembelajaran dengan cara tertulis (Indrawati, 2009). Jenis penilaian biasa. Oleh karena itu semua asas yang terpadu terdiri atas tes dan bukan tes. diperhatikan dalam penilaian hasil belajar Sistem penilaian dengan menggunakan tes 
merupakan sistem penilaian konvensional. karena itu untuk melengkapi gambaran Sistem ini kurang dapat menggambarkan kemajuan belajar secara menyeluruh maka kemampuan peserta didik secara dilengkapi dengan non-tes (Balitbang menyeluruh, sebab hasil belajar Depdiknas, 2006) seperti terlihat pada digambarkan dalam bentuk angka yang Gambar 2 gambaran maknanya sangat abstrak. Oleh

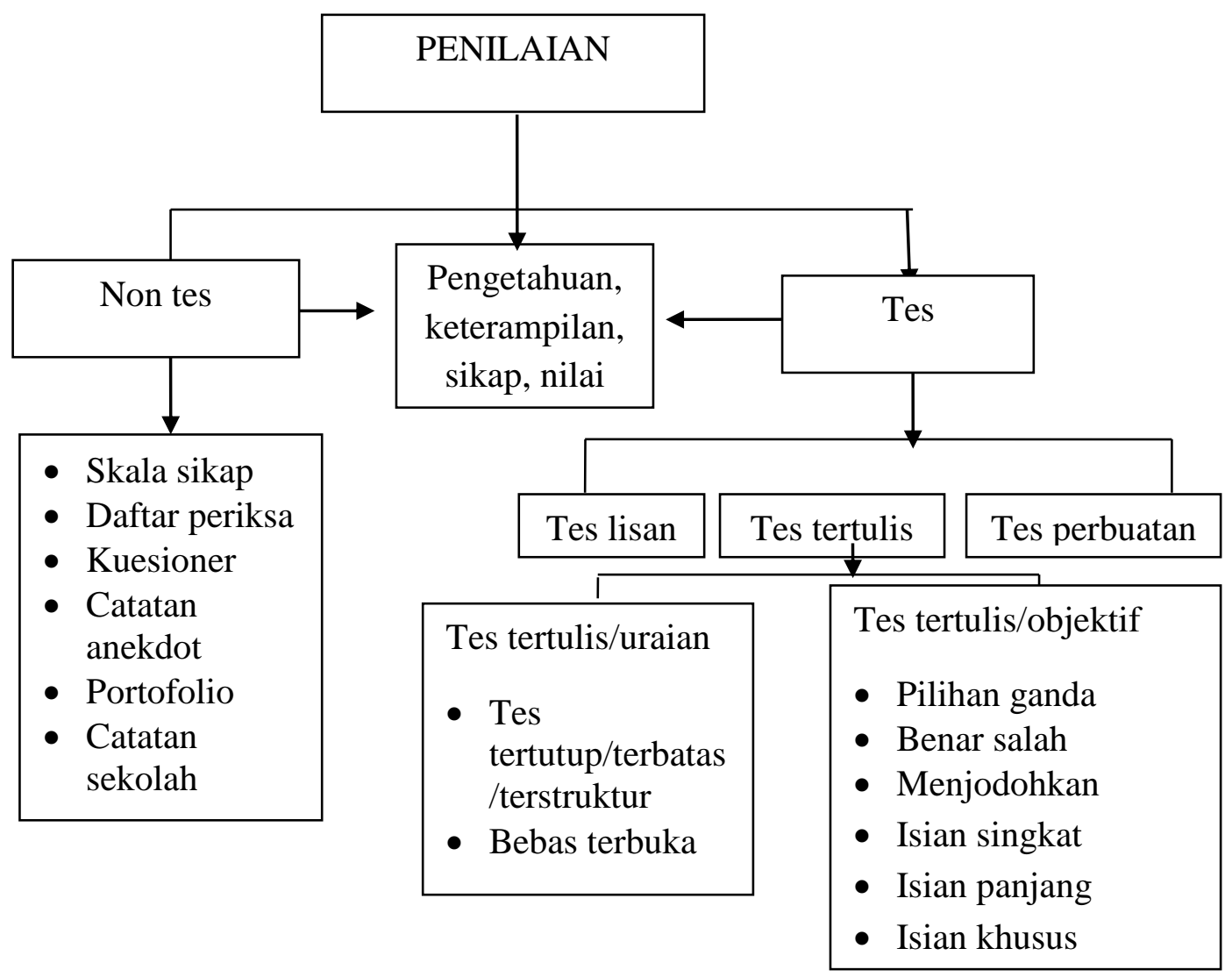

Gambar 2 Model Penilaian Pembelajaran Terpadu (Balitbang Depdiknas, 2006)

Guru dapat mempraktikkan kemampuan berfikir kritis dan kreatif beberapa teknik penilaian. Penilaian non- serta keterampilan siswa dalam berinkuiri tes dapat dilakukan dengan menganalisis dapat dievaluasi juga. Dalam masalah dan usulan cara pembelajaran terpadu, siswa sibuk, aktif penanggulangannya. Melalui observasi dan terlibat. Guru hendaknya selalu dan inferensiasi, perkembangan membuat catatan akan aksi dan reaksi 
siswa yang kemudian dianalisis. Hasil analisis juga dapat dipakai sebagai bahan pertimbangan dalam menilai proses pembelajaran terpadu (Trianto, 2007).

3. Integrasi Potensi Pertanian Lokal dalam Pembelajaran IPA Terpadu di Sekolah Menengah
Integrasi potensi pertanian lokal dalam pembelajaran terpadu dapat dilaksanakan dengan pengambilan tema pertanian lokal yang ada didaerah tersebut. Seperti halnya contoh pemaduan dalam tema "padiku subur hidupku makmur" dapat dilihat pada Gambar 3.

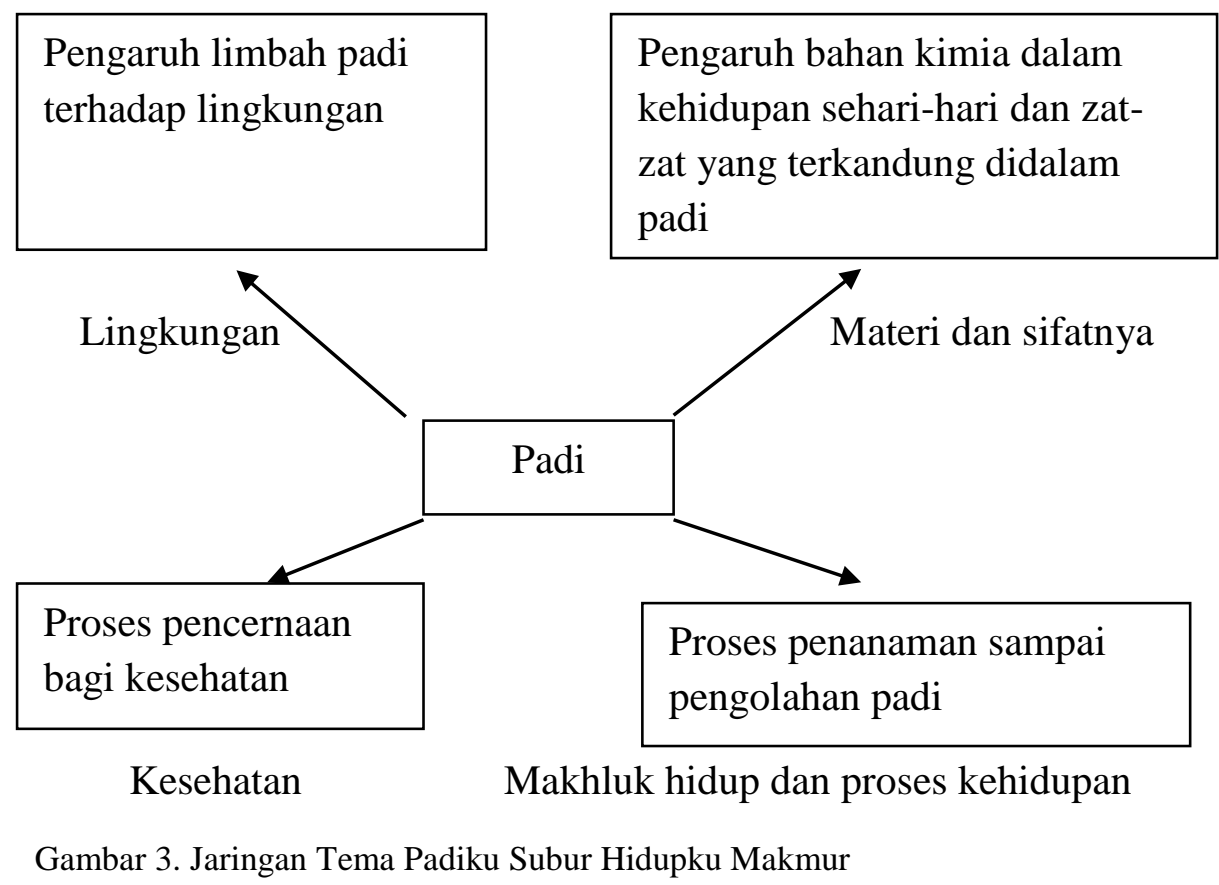

\section{KESIMPULAN}

Model pembelajaran terpadu adalah suatu pendekatan pembelajaran yang melibatkan beberapa bidang studi untuk memberikan pengalaman yang bermakna kepada siswa. Bermakna artinya dalam pembelajaran terpadu, siswa akan memahami konsep-konsep yang mereka pelajari melalui pengalaman langsung dan menghubungkannya dengan konsep lain yang sudah mereka pahami. Sedangkan IPA terpadu adalah sebuah pendekatan integratif yang mensintesis perspektif (sudut pandang/tinjauan) semua bidang kajian dalam IPA untuk memecahkan permasalahan. IPA terpadu adalah suatu pendekatan pembelajaran IPA yang menghubungkan atau menyatu-padukan 
berbagai bidang kajian IPA menjadi satu kesatuan bahasan. Pembelajaran IPA secara terpadu juga harus mencakup dimensi sikap, proses, produk, aplikasi, dan kreativitas.

Model pembelajaran IPA terpadu direkomendasikan di tingkatan SMP/MTs, karena ternyata memiliki beberapa tujuan, yaitu: meningkatkan efesiensi dan efektivitas pembelajaran; meningkatkan minat dan motivasi, serta beberapa kompetensi dasar dapat dicapai sekaligus. Model pembelajaran IPA terpadu juga memiliki beberapa kekuatan dan manfaat, yaitu: penggabungan berbagai bidang kajian terjadi penghematan waktu, karena tiga disiplin ilmu (fisika, kimia dan biologi) dapat sekaligus dibelajarkan.

Implementasi pembelajaran terpadu sesuai dengan sifat keterpaduannya pembelajaran terpadu yang dibedakan menjadi tiga, yakni model dalam satu disiplin ilmu (model yang masuk ke dalam kelompok ini antara lain adalah fragmented model, connected model, nested model), model antar bidang (model keperpaduan yang masuk ke dalam kelompok ini antara lain sequenced model, shared model, webbed model, threaded model, integrated model), dan model dalam lintas siswa (model keperpaduan yang masuk ke dalam kelompok ini antara lain immersed model dan networked model).

Integrasi potensi pertanian lokal dalam pembelajaran terpadu dapat dilaksanakan dengan pengambilan tema pertanian lokal yang ada didaerah tersebut. Seperti halnya contoh pemaduan dalam tema "padiku subur hidupku makmur" yang dapat diintegrasikan halhal yang berkaitan dengan pertanian padi sebagai produk potensi lokal setempat. Sehingga nantinya potensi pertanian lokal tetap terjaga dan dapat dikembangkan lebih lanjut.

\section{SARAN}

Beberapa saran yang dapat dikemukakan antara lain: Implementasi model pembelajaran IPA terpadu dapat dilaksanakan baik dengan cara melihat karakteristik KD yang akan dipertautkan atau dihubungkan agar dapat terasa terpadu dan tidak terkesan pemaksaan dalam pemaduan. (2) pendidik hendaknya mengintegrasikan potensi pertanian lokal dalam pembelajaran agar tetap terjaga dan dapat dikembangkan lebih lanjut. 


\section{DAFTAR RUJUKAN}

Balitbang Depdiknas. 2006. Panduan Pengembangan Pembelajaran IPA Terpadu SMP/MTs. Pusat Kurikulum Jakarta Pusat.

Depdiknas. 2008. Kurikulum Tingkat Satuan pendidikan. Dikmenum, Depdiknas. Jakarta

Dinas pertanian Grobogan. 2013.

www.bkp.grobogan.co.id., diakses pada 01 Februari 2014.

Hidayat, N. 2009. 'Pengembangan Pembelajaran Terpadu Model Connected untuk Meningkatkan hasil Belajar Siawa Dalam Mata Pelajaran Ilmu pengetahuan Alam. Inovasi Kurikulum, Thn.4, ISSN: 1829-6750, 1(4): 15-29.

Indrawati. 2009. Model Pembelajaran Terpadu di Sekolah Dasar. Jakarta: Pusat Pengembangan dan Pemberdayaan Pendidik dan Tenaga Kependidikan Ilmu Pengetahuan Alam.

Muhlisin, A. 2012. Pengembangan Perangkat Pembelajaran IPA Terpadu Berbasis Contextual Teaching and Learning (CTL) Dengan Model Pembelajaran Kooperatif Tipe STAD Tema Polusi udara. Jurnal of Educational Research and Learning, ISSN 2252-6420. 1 (2): 139-145.

Pemerintah Kabupaten Grobogan. 2013. www.Kab.Grobogan.go.id, diakses pada 01 Februari 2014.

Trianto. 2007. Model Pembelajaran Terpadu dalam Teori dan Praktek. Prestasi Pustaka. Jakarta. 